\title{
OPHTHALMOLOGICAL FACILITY FUNCTIONALITY: A SELECTION OF CASES
}

\section{FUNKCJONALNOŚĆ OŚRODKÓW OKULISTYCZNYCH NA WYBRANYCH PRZYKŁADACH}

\author{
Michał Kiszkielis \\ Mgr inż. arch. \\ Author's Orcid number: 0000-0002-2316-6711 \\ West Pomeranian University of Technology in Szczecin \\ Faculty of Civil Engineering and Architecture \\ Chair of Urban Design and Spatial Planning
}

\section{Adriana Kiszkielis}

Dr n. med.

Author's Orcid number: 0000-0002-2826-9648

Pomeranian Medical University in Szczecin

Department of Ophthalmology

\begin{abstract}
A medical centre is one of the most complex building types to design because it requires complete understanding of work organisation and the disabilities faced by patients. Based on personal observations and the literature, selected ophthalmic centres around the world were analysed, with a focus on design solutions that improve their functionality. Instituto de Microcirurgia Ocular is characterised by a very well-thought-out arrangement of rooms. The Harkness Eye Institute is an excellent example of the modernisation of an almost century-old building. During the design of the Richard Desmond Children's Eye Centre, inspiration was sought in the medical world, creating an interior that was extremely child-friendly.
\end{abstract}

Key words: interior design, medical centre, ophthalmic hospital.

\section{STRESZCZENIE}

Ośrodek medyczny stanowi jeden z najbardziej złożonych typów budynków do zaprojektowania, ponieważ wymaga pełnego zrozumienia problematyki organizacji pracy personelu oraz niepełnosprawności z jakimi zmaga się chory. Na podstawie własnych obserwacji i dostępnej literatury poddano analizie wybrane ośrodki okulistyczne na świecie zwracając uwagę na zastosowane rozwiązania projektowe, które poprawiają ich funkcjonalność. Instituto de Microcirurgia Ocular charakteryzuje się bardzo przemyślanym układem pomieszczeń. Harkness Eye Institute to doskonały przykład modernizacji prawie stuletniego budynku. Z kolei przy tworzeniu Richard Desmond Children’s Eye Centre szukano inspiracji w świecie medycznym tworząc wnętrze niezwykle przyjazne dla dzieci.

Słowa kluczowe: ośrodek medyczny, projekt wnętrza, szpital okulistyczny. 


\section{GENERAL INFORMATION}

Architecture can, to a certain degree, be compared with acting. Prior to a performance, the actor must get to know their character, their strengths and weakness, their character, dreams and goals. The task placed before the architect prior to beginning the design process of a public building, and especially a medical centre, is very similar. The designer must not only enter the role of a member of the medical staff, but most importantly that of a person with a medical condition, a patient with certain limitations, and account for epidemiological solutions. The correct design of technology and function can meet all of these requirements. To determine the best functional and technological solutions, the author investigated three selected ophthalmology centres located in Barcelona, New York and London.

The objective of the study presented in this paper was the analysis of selected ophthalmological centres in terms of their functionality, as seen from the perspective of an ophthalmologist and an architect, in everyday medical practice. The study was based on an analysis of the literature, personal observations of the operation of selected ophthalmological centres from the standpoint of an ophthalmologist and an architect.

\section{IMO INSTITUTO DE MICROCIRURGIA OCULAR IN BARCELONA}

The IMO Instituto de Microcirurgia Ocular in Barcelona is undoubtedly an example of a welldesigned ophthalmological centre. The location of the site, due to its placement between the busy La Ronda de Dalt bypass from the south and the Sierra de Collserola mountain range from the north, posed a considerable challenge. The design had to address the natural conditions of the terrain, which were completely different to what can be considered 'urban'. The main design idea was focused on utilising the topography and slopes in the terrain, which turned out to be key tools in determining the building's morphology, as highlighted by the architect of the building, Josep Llinas. The massing of the IMO is in no way dominant, as instead it excellently blends into the mountainside, creating what is described as a ha-ha wall between the urban fabric and the landscape. The structural system of the building comprises five storeys below three deformed roof surfaces, each of which is elevated, forming a sequence of shaded courtyards. They are divided into internal and external courtyards, from which there is a beautiful view of Barcelona's panorama. This contributes to a total floor area of $24,000 \mathrm{~m}^{2}$, The entrance to the building faces a side street and leads through an open arcade to the building's main spaces (Fig. 1,2). The main point that begins every visit at the IMO is a spacious waiting room beside the reception space, where the roof attracts the greatest deal of attention. A part of it consists of skylights divided by pergolas, which were described by architect J. Llinas as eyelashes, while the windows in the waiting room are intended to bring to mind associations with the cornea-the most translucent element of the eye. The layout of the skylights and the number of windows results in an illumination that is easy on the eyes, which is essential in the case of a facility that specialises in eye disorders.

Ophthalmological patients require comfort, which is why light cannot be blinding. It should be evenly scattered and soothing. Another of the waiting room's positive characteristics is its considerable floor area. It provides the patient with a little privacy while waiting for stressful examinations or procedures. It should be noted that visits to an ophthalmologist are not short, as numerous examinations and imaging tests are required, as is waiting for the pupils to dilate after the application of proper eye-drops. The spacious waiting room also allows the centre to function during a pandemic, as it allows the safe isolation of patients while they await their appointment. We shall probably see pandemics like COVID-19 more frequently, which is why the planning of medical facilities should account for design solutions that can ensure the continued offering of medical care even during a pandemic threat. From this standpoint, creating separate corridors for patients and personnel, as is the case in the IMO, is highly rational. Every office has two separate entrances, one for personnel and one for patients, which makes the functioning of the Institute easier. To facilitate the centre's operation, it features an auditorium for an audience of 300, eight operating rooms, 20 diagnostic rooms, 60 consultation rooms, a molecular biology laboratory and numerous dedicated spaces for personnel, such as a library, cafeteria or a room for rest. 
The type of medical equipment is largely the same in highly developed countries. However, in the case the IMO, it is its amount that is impressive, or rather the numerousness and quality of welldesigned and equipped spaces. Without a doubt, employing a sufficient number of employees and good organisation of physicians, optometrists, nurses and equally important auxiliary personnel allows the entire complex to function harmoniously and each staff member to comfortably attend to their duties. This contributes to an atmosphere of order and calmness, not to mention comfort and maintaining patient privacy.

In the case of ophthalmological facilities, certain spaces should not have access to sunlight. These include operating and consultation rooms, as testing the frontal section of the fundus of the eye and most procedures are performed under a microscope and in the dark. Due to these dependencies, the southern façade is open towards the city, while the northern one blends into the mountainside, where the rooms without access to daylight are located. In addition, the building has two underground storeys used as, among others, a car park for around 200 vehicles. Undoubtedly, it is one of the most modern ophthalmological centres where well-thought-out design solutions were applied, providing work hygiene to personnel and comfort to patients.

Based on personal observations of IMO Instituto, IMO 2013, Institute of Ocular Microsurgery 2009 and IMO 2011.

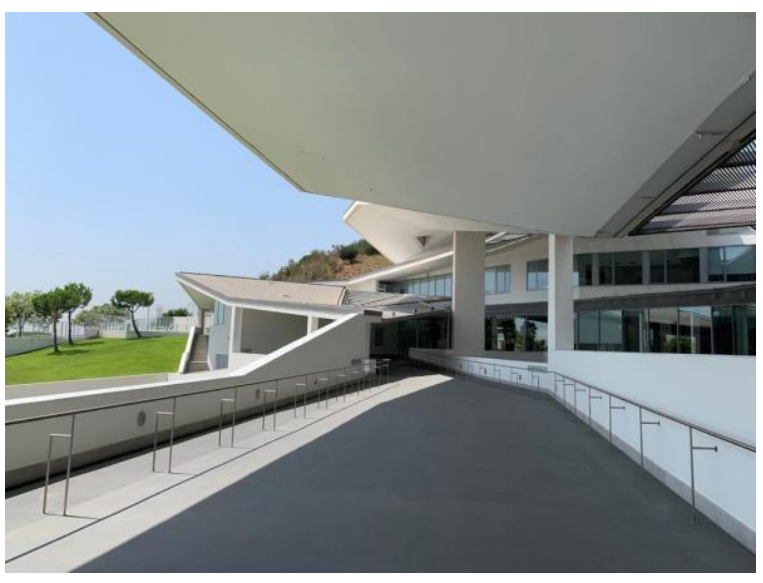

Fig. 1. IMO Instituto de Microcirurgia Ocular, Barcelona. Source: Original photo, 2019

Ryc. 1. IMO Instituto de Microcirurgia Ocular w Barcelonie. Źródło: Zdjęcia własne autorki, wykonane w 2019 roku

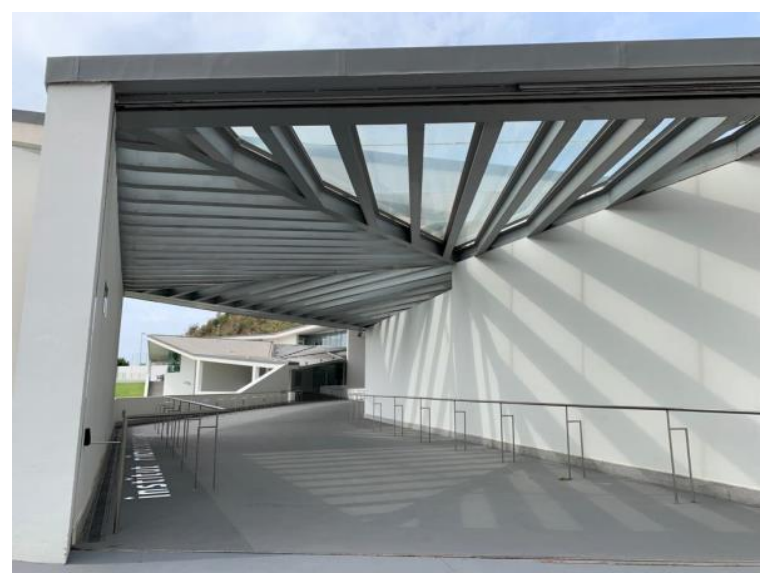

Fig. 2. IMO - Main entrance. Source: Original photo, 2019 Ryc. 2 IMO - wejście główne. Źródło: Zdjęcia własne autorki, wykonane w 2019 roku

\section{THE EDWARD S. HARKNESS EYE INSTITUTE IN NEW YORK}

The Edward S. Harkness Eye Institute in New York is a different example of a well-thought-out ophthalmological hospital (Fig. 3) that was built in 1928 in the Modernist style. Due to constant improvements, this building, which is over a century old, has ceaselessly been operating not only as a treatment and diagnostics centre, but also a global centre of research on eye disorders. The solutions and innovations that were implemented in it already during the original design process in the previous century are indeed praiseworthy. Operating rooms with glass-domed ceilings for the observation of procedures were indeed visionary in those times. The building also did not lack residential spaces for personnel, libraries, cafeterias, conference halls and an extensive network of diagnostics and operating rooms. Over time, a series of modifications were made, adapting the building in terms of safety. The modernisations included not only facilities for personnel, but also patients with eye disorders, whose needs were being understood increasingly well at the time. Thus, a high contrast between horizontal and vertical surfaces was applied, in addition to neutrally coloured floors, tactile differences in materials and the previously mentioned anti-glare, even illumi- 
nation. These changes maintain a cohesive character throughout the building, which is also an educational facility through being a part of Columbia University. Nearby is the exhilarating Roy and Diana Vagelos Education Center (Fig. 4), adapted to, among other things, various types of training seminars on operating techniques addressed to adepts of ophthalmology and other specialisations. Based on personal observations and interviews performed at the Harkness Eye Institute 2017, Edward S. Harkness Eye Institute and Dattner Architects 2017.

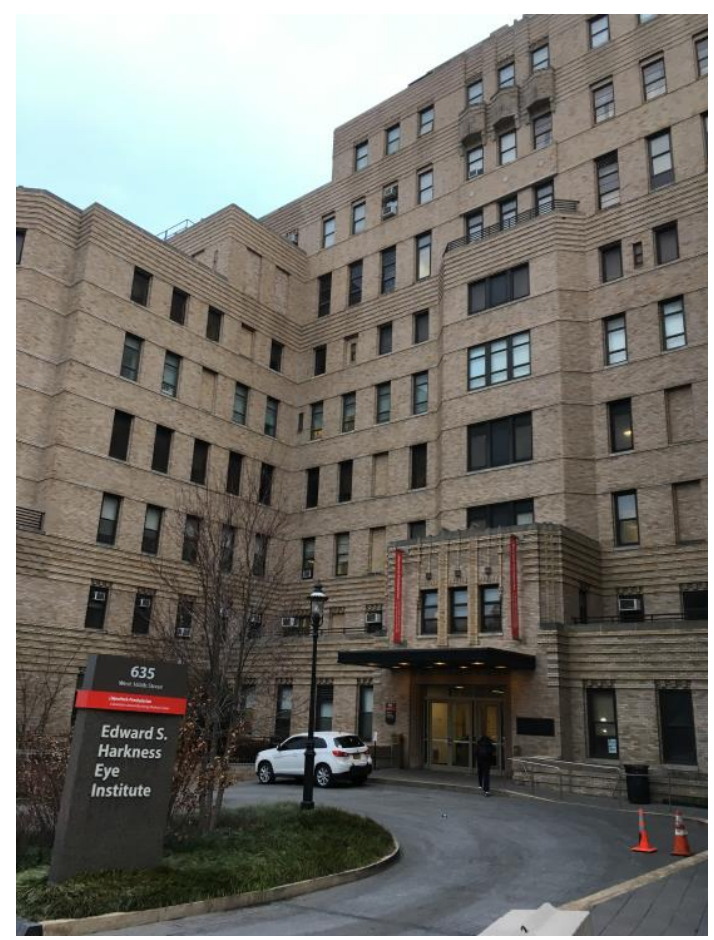

Fig. 3. Edward S. Harkness Eye Institute. Source: Original photo, 2020

Ryc. 3. Edward S. Harkness Eye Institute. Źródło: Zdjęcia własne autorki, wykonane w 2020 roku

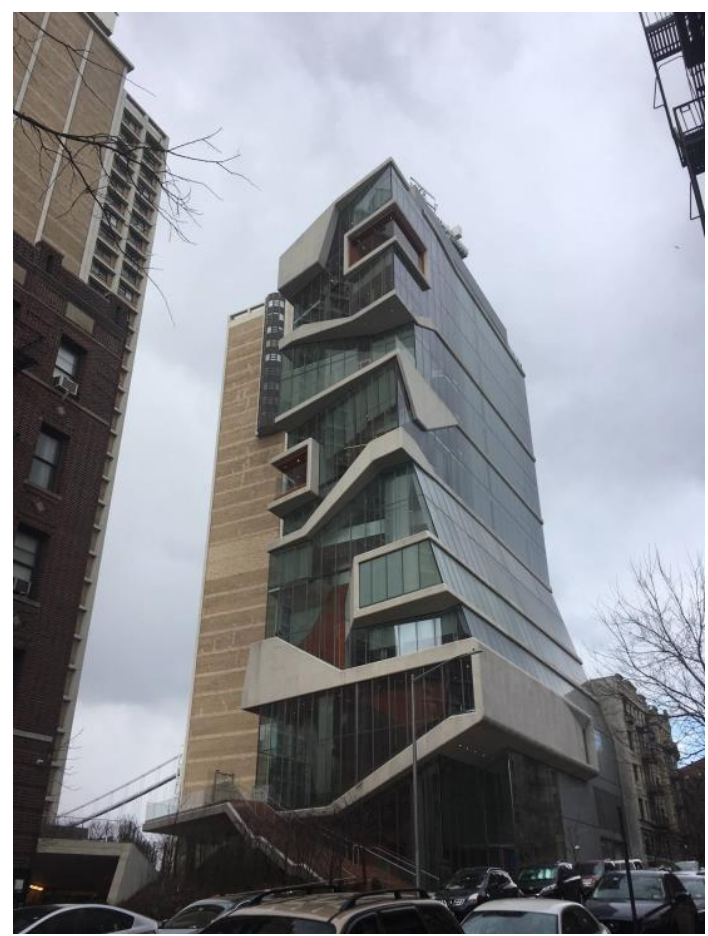

Fig. 4. Vagelos Education Center. Source: Original photo, 2020

Ryc. 4. Vagelos Education Center. Źródło: Zdjęcia własne autorki, wykonane w 2020 roku

\section{RICHARD DESMOND CHILDREN'S EYE CENTRE IN LONDON}

The children's ward of Moorfields Eye Hospital was designed by Penoyre \& Prasad, winning international acclaim in the design sector. The building is also featured on the list of '25 Most Amazing Hospitals in the World' compiled by 'Best Master of Science in Nursing'. There are a number of reasons for this. Of note is most certainly its façade, designed in tandem with Alison Turnbull, who sought inspiration in stencils and drawings (Fig. 5) associated with optometry. The artist's attention was caught the most by the Amsler grid test, used to gauge the activity of the central part of the retina - the macula. Patients with macular disorders who look at a central point on a grid of parallel and perpendicular black lines can see them as distorted. This symptom became an inspiration in the later creative process, as Turnbull crumpled grids drawn on paper, which, after straightening, formed different patterns, similarly to those seen by patients with central retina disorders. In the end, a frontal façade comprised of 'shaky' foldable aluminium blinds was built, producing an illusion of swirling movement. To highlight the effect of variegation, it was decided to have the outer elements made in three shades of silvery grey. During the day, the façade reduces the insolation inside the building, while at dusk, a custom lighting sequence douses the building in dynamic, shining colours (Fig. 6). 


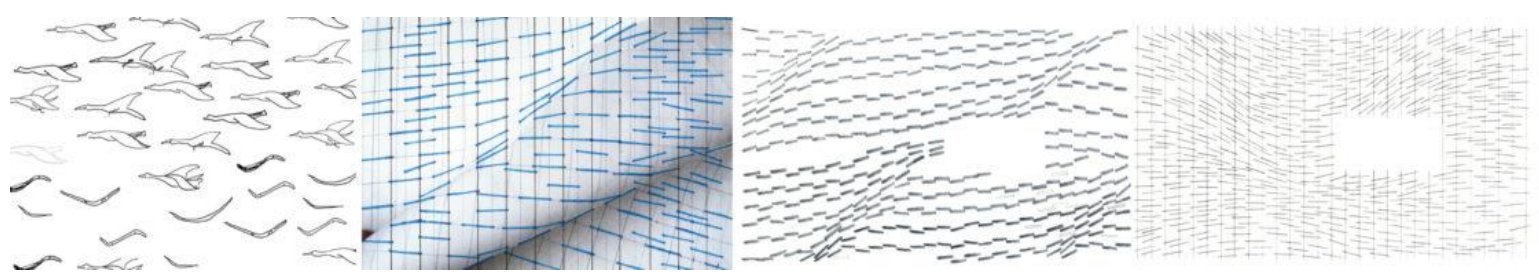

Fig. 5. Façade-conceptual proposal. Source: "www.penoyreprasad.com"

Ryc. 5. Fasada - koncepcja. Źródło: www.penoyreprasad.com

Fig. 6. Richmond Desmond Children's Eye Centre. London. Source: Children's Eye Centre

Ryc. 6. Richmond Desmond Children's Eye Centre. Londyn. Źródło: Children's Eye Centre

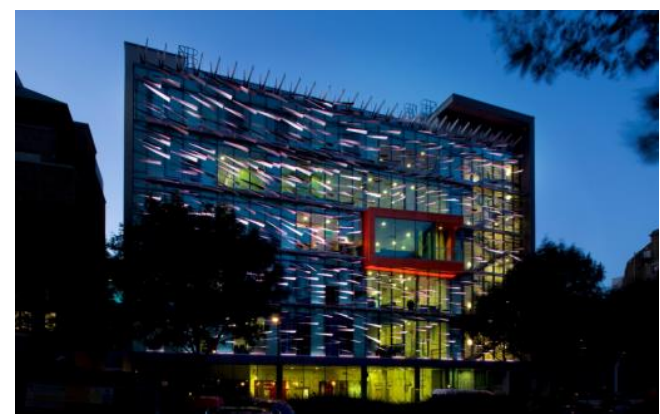

Another element that was taken from the medical world is the ocular path diagram (Fig. 7) presented in the form of a mural, which stretches across each of the building's five floors and connects the ground-floor entrance with the main waiting rooms above. This makes the building connected vertically and produces the impression of a colossal space. The author, Yuko, Shiraishi, used over 30 different colours in her work, utilising separate colour schemes at every storey, where each floor has a similar number of shades. This procedure builds an atmosphere of calmness and facilitates regeneration, particularly in waiting rooms, which Prasad called 'transition periods and spaces inbetween'. The children-friendly interior was also decorated with visual works by famous female artists. Lucy Casson's forest dwellers were installed on internal concrete columns, while Samantha Bryan's fairies were placed on round, transparent domes that reference the windows of the eastern façade.

The Richard Desmond Children's Eye Centre is the largest paediatric ophthalmology research centre as a combination of the Institute of Ophthalmology and the Moorfields Eye Hospital. It was designed entirely with children and their parents in mind, providing them with treatment in the best possible conditions. As highlighted by Professor Penr T. Khaw, 'this building changed the way in which we can treat patients'.

Based on Children's Eye Centre, Moorfields Eye Hospital and personal observations.

Fig. 7. Interior design and mural by Yuko Shiraishi. Source: Children's Eye Centre

Ryc. 7. Wnętrze z muralem autorstwa Yuko Shiraishi. Źródło: Children's Eye Centre

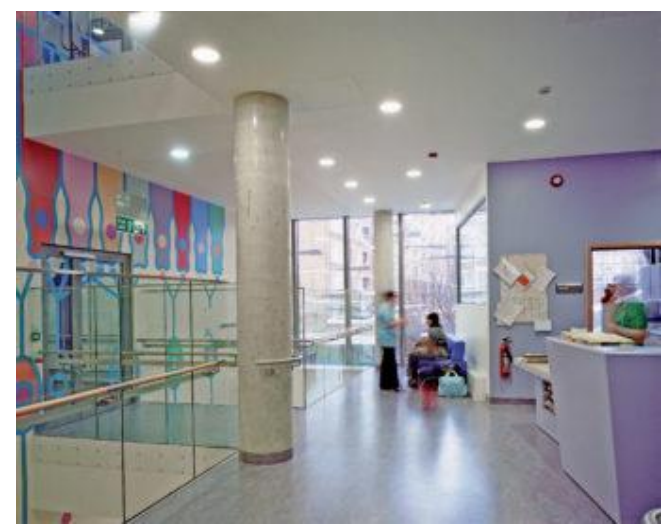




\section{CONCLUSIONS}

The quality of medical procedures or the equipment used for testing in developed countries is at a similar level. That which sets Polish ophthalmological centres apart from the selected cases presented in the paper is primarily the comfort of work enjoyed by personnel and the patients' comfort during their stay in the hospital. This is caused by an insufficient budget, as healthcare is not free and is typically very expensive. One of the aspects that makes work considerably more difficult is the lack of properly adapted diagnostics and operating rooms. Typically, public hospitals and medical centres are housed in old, pre-war buildings where large-scale remodelling is problematic. Diagnostics rooms typically have an insufficient number of desks relative to the number of employed physicians or there are too few seats in narrow waiting rooms, where patients and those who accompany them must wait standing, often for several hours. However, it is difficult to expect the problem of room functionality and aesthetics to be solved in light of more urgent needs, such as the limit of medical services that can be offered or widespread staff shortages among many groups of medical personnel. It should also be noted that the presented cases of ophthalmological centres are model facilities in many respects and their establishment was associated with immense financial expenditure and the involvement of numerous architects, structural engineers and other building services engineers and specialists. The IMO in Barcelona is characterised by highly accurate solutions in terms of the function it performs, and its architecture addresses the matter of aggressive light through properly shading each zone. During the pandemic, the placement of circulation paths between each of the centre's zones outdoors and having the rooms and hallways properly divided into separate sections for patients and physicians turned out to be good solutions. The Harkness Eye Institute is proof that even a century-old building can be adapted to current standards and needs. The Children's Eye Centre in London creates a children-friendly atmosphere and demonstrates just how much inspiration can be taken from the world of medicine. The application of joyful colours and fairy-tale decorative elements creates a comfortable atmosphere for young patients.

In Poland, there is a number of examples of either partially or fully privately owned multi-specialist centres. However, they cannot possibly compete with the buildings under study in architectural, planning, functional and aesthetic terms. The much greater number of operating and consultation rooms alone generates a stark difference. The centres presented in the paper should serve as a model of correct design solutions, as well as of the work organisation to be followed by physicians and personnel.

\section{FUNKCJONALNOŚĆ OŚRODKÓW OKULISTYCZNYCH NA WYBRANYCH PRZYKŁADACH}

\section{INFORMACJE OGÓLNE}

Architekturę w pewnym stopniu można porównać do aktorstwa. Aktor przed spektaklem musi poznać swoją postać, jej mocne, słabe strony, charakter, marzenia i cele. Bardzo podobne zadanie stawiane jest architektowi przed przystąpieniem do procesu projektowego, budynku użyteczności publicznej, zwłaszcza ośrodka medycznego. Projektant bowiem musi wejść nie tylko w rolę personelu medycznego ale przede wszystkim człowieka chorego, pacjenta z pewnymi ograniczeniami jak również wziąć pod uwagę rozwiązania epidemiologiczne. Prawidłowe zaprojektowanie technologii i funkcji zapewni te wszystkie wymagania. Dla określenia najlepszych rozwiązań funkcjonalnych i technologicznych przeprowadzono badania w wybranych, trzech ośrodkach okulistycznych znajdujących się w Barcelonie, Nowym Jorku i Londynie.

Celem tej pracy jest analiza wybranych ośrodków okulistycznych pod względem ich funkcjonalność z perspektywy lekarza okulisty i architekta w codziennej praktyce lekarskiej. Metoda badań opierała 
się na analizie literatury, własnych obserwacjach związanych z funkcjonowaniem wybranych ośrodków okulistycznych od strony lekarza okulisty i architekta.

\section{IMO INSTITUTO DE MICROCIRURGIA OCULAR W BARCELONIE}

Przykładem dobrze zaprojektowanego ośrodka okulistycznego jest niewątpliwie IMO Instituto de Microcirurgia Ocular w Barcelonie. Dużym wyzwaniem stanowiła lokalizacja terenu z uwagi na położenie działki pomiędzy ruchliwą obwodnicą La Ronda de Dalt od południa oraz pasmem górskim Sierra de Collserola od północy. Projekt musiał być odpowiedzią na naturalne warunki ukształtowania otoczenia, zupełnie odmienne niż 'miejskie'. Główna idea projektowa skoncentrowała się zatem na wykorzystaniu topografii oraz nachyleń terenu, które stały się kluczowym narzędziem do określenia morfologii budynku, co zresztą podkreśla sam architekt Josep Llinas. Bryła IMO w żaden sposób nie jest dominująca, lecz świetnie wkomponowana w górskie zbocze tworząc swojego rodzaju ścianę ( ha-ha wall) pomiędzy tkanką miejską a krajobrazem. Konstrukcję budynku tworzy pięć kondygnacji pod trzema zniekształconymi połaciami dachu, z których każdy kolejny jest podniesiony, tworząc nitkę zacienionych dziedzińców. Dzielą się one na wewnętrzne jak i zewnętrzne, skąd rozpościera się piękna panorama Barcelony. Składa się to na łączną powierzchnię $24000 \mathrm{~m}^{2}$. Wejście do budynku usytuowane jest od bocznej uliczki i prowadzi przez otwartą arkadę do głównych pomieszczeń (Ryc. 1, 2). Głównym punktem, od którego zaczyna się każda wizyta w IMO jest przestronna poczekalnia zaraz obok recepcji, gdzie największą uwagę zwraca dach. Jego część stanowią świetliki poprzedzielane przez pergole, które architekt J. Llinas porównuje do rzęs, natomiast okna w poczekalni nasuwają na myśl rogówkę- najbardziej przejrzysty element oka. Rozplanowanie świetlików oraz ilość okien tworzy łagodne oświetlenie dla wzroku co w przypadku ośrodka specjalizującego się w chorobach oczu jest niezwykle istotne.

Pacjent okulistyczny potrzebuje uczucia komfortu dlatego światło nie może oślepiać, powinno być jednakowo rozproszone i dawać uczucie ukojenia. Następną zaletą poczekalni jest jej powierzchnia. Daje to pacjentowi nieco prywatności w chwili oczekiwania na stresujące badania czy operację. Warto zaznaczyć, że wizyta okulistyczna nie jest krótka, często wymaga szeregu testów, badań obrazowych oraz oczekiwania na rozszerzenie się źrenic po podaniu odpowiednich kropli. Przestronna poczekalnia pozwala też na funkcjonowanie ośrodka w czasie epidemii, ponieważ umożliwia na bezpieczne odseparowanie chorych podczas oczekiwania na wizytę. Prawdopodobnie coraz częściej będziemy świadkami wybuchu pandemii, jak COVID-19, dlatego w planowaniu ośrodków medycznych powinno się brać pod uwagę rozwiązania projektowe, mogą zachować ciąg udzielania świadczeń medycznych w obliczu zagrożenia epidemią. Z tego punktu widzenia bardzo rozsądne jest stworzenie osobnych korytarzy dla chorych oraz personelu, tak jak ma to miejsce w IMO. Każdy gabinet posiada dwa osobne wejścia dla personelu i pacjentów co niewątpliwie ułatwia funkcjonowanie Instytutu. Na potrzeby swobodnej działalności ośrodka zaplanowano bowiem audytorium mogące pomieścić 300 osób, osiem sal operacyjnych, 20 gabinetów diagnostycznych, 60 gabinetów konsultacyjnych, laboratorium biologii molekularnej oraz wiele sal dedykowanych personelowi jak biblioteka, jadalnia czy pokój odpoczynku.

Rodzaj sprzętu medycznego nie rożni się w dużym stopniu w poszczególnych krajach wysoko rozwiniętych. Jednak w przypadku IMO imponująca jest jego ilość, a raczej liczebność i jakość zaprojektowanych oraz wyposażonych pomieszczeń. Bez wątpienia zatrudnienie odpowiedniej liczby pracowników i dobra organizacja pracy lekarzy, optometrystów, pielęgniarek oraz równie ważnego personelu pomocniczego pozwala na harmonijne funkcjonowanie całego zespołu jak również komfortowe wykonywanie obowiązków każdego z osobna. Wpływa to na budowanie atmosfery porządku i spokoju, nie wspominając nawet o komforcie i zachowaniu prywatności pacjenta.

Niektóre pomieszczenia w przypadku ośrodka okulistycznego, nie powinny mieć dostępu do światła dziennego. Mowa tutaj o salach operacyjnych oraz pokojach konsultacyjnych, bowiem badanie przedniego odcinka oraz dna oka jak również większość operacji wykonywana jest przy pomocy mikroskopu, odbywa się w ciemności. Z powodu wymienionych zależności południowa fasada IMO otwarta jest w stronę miasta, z kolei północna wtopiona w górskie zbocze, gdzie właśnie usytuow- 
ane są pomieszczenia pozbawione dziennego światła. Dodatkowo budynek posiada dwie kondygnacje podziemne wykorzystane m.in. na parking mogący pomieścić około 200 pojazdów. Bez wątpienia jest to jeden z najnowocześniejszych ośrodków okulistycznych, gdzie zastosowano przemyślane rozwiązania projektowe, zapewniając higienę pracy personelowi oraz komfort pacjentom.

Opracowano na podstawie własnych obserwacji IMO Instituto, IMO 2013, Institute of Ocular 2009 i IMO 2011.

\section{THE EDWARD S. HARKNESS EYE INSTITUTE W NOWYM JORKU}

Odmiennym przykładem przemyślanego szpitala okulistycznego jest The Edward S. Harkness Eye Institute w Nowym Jorku (Ryc. 3), który został zbudowany w 1928 roku w stylu modernistycznym. Dzięki ciągłym ulepszeniom ten prawie stuletni budynek nieprzerwalnie pełni funkcję nie tylko ośrodka leczniczo-diagnostycznego, ale również światowego centrum badań naukowych nad chorobami oczu. Godne pochwały są rozwiązania i innowacje, które zostały wdrożone jeszcze na pierwotnym etapie procesu projektowego w ubiegłym wieku. Niewątpliwie wizjonerskie w tych czasach okazały się sale operacyjne $z$ kopulastymi przeszkleniami w suficie służące do obserwacji przebiegu zabiegów. Nie zabrakło też pomieszczeń mieszkalnych dla personelu, bibliotek, jadalni, sal konferencyjnych oraz rozległej sieci pokojów badań oraz gabinetów zabiegowych. Z biegiem czasu wprowadzono szereg zmian dostosowując budynek w kwestii bezpieczeństwa. Modernizacje uwzględniały nie tylko udogodnienia dla personelu, ale przede wszystkim pacjentów niedowidzących, których potrzeby zaczęto rozumieć coraz bardziej. Tym samym zastosowano wysoki kontrast pomiędzy powierzchniami poziomymi a pionowymi, stonowane kolorystycznie podłogi, dotykowe zróżnicowanie materiałów oraz wspomniane już nieoślepiające, pośrednie oświetlenie. Wdrożone zmiany utrzymują spójny charakter w całym budynku, który pełni również funkcję dydaktyczną poprzez przynależność do Columbia University. W bliskim sąsiedztwie znajduje się zachwycający The Roy and Diana Vagelos Education Center (Ryc. 4) przystosowany m.in. do przeprowadzenia różnego rodzaju szkoleń z technik operacyjnych adeptów okulistyki oraz innych specjalności.

Opracowano na podstawie własnych obserwacji i wywiadów oraz Harkness Eye Institute 2017, Edward S. Harkness Eye Institute i Dattner Architects 2017.

\section{RICHARD DESMOND CHILDREN'S EYE CENTRE W LONDYNIE}

Oddział dziecięcy Moorfields Eye Hospital został zaprojektowany przez studio Penoyre \& Prasad zdobywając międzynarodowe uznanie $w$ branży projektowej. Budynek figuruje też na liście '25 Most Amazing Hospital in the World' stworzonej przez 'Best Master of Science in Nursing'. Powodów jest kilka. Uwagę z pewnością przykuwa elewacja stworzona w tandemie z Alison Turnbull, która poszukiwała inspiracji w szablonach i rysunkach (Ryc. 5) związanych z optyką.. Artystkę najbardziej zainteresował test Amslera, używany do oceny czynności centralnej części siatkówkiplamki. Pacjentowi z chorobą plamki spoglądającemu na centralny punkt na siatce czarnych prostopadłych i równoległych linii mogą się one wydawać zniekształcone. Objaw ten okazał się inspirujący $w$ dalszym procesie twórczym, Turnbull gniotła ortogonalne siatki narysowane na papierze, które po wyprostowaniu stanowiły już inny wzór, podobnie jak u części pacjentów z chorobą centralnej siatkówki. Finalnie powstała frontowa elewacja z 'chybotliwych' składanych aluminiowych żaluzji dająca złudzenie ruchu wirowego. Dla podkreślenia efektu wariegacji zdecydowano utrzymać elementy zewnętrze $w$ trzech odcieniach srebrnej szarości. W ciągu dnia elewacja zmniejsza nasłonecznienie wewnątrz budynku z kolei o zmierzchu zaprojektowana sekwencja świetlna zalewa budynek dynamicznymi, świecącymi kolorami (Ryc. 6).

Kolejnym elementem zaczerpniętym ze świata medycznego jest diagram drogi wzrokowej (Ryc.7) przedstawiony $w$ formie muralu, który rozciąga się na wszystkie pięć pięter i łączy wejście na parterze z głównymi poczekalniami powyżej. Dzięki temu budynek połączony jest w pionie oraz daje uczucie kolosalnej przestrzeni. Autorka Yuko Shiraishi w swojej pracy zastosowała ponad 30 różnych barw i użyła oddzielne schematy kolorystyczne na każdej kondygnacji, gdzie poszczególne 
piętra zawiera podobną ilość odcieni. Taki zabieg buduje atmosferę spokoju, sprzyja regeneracji w szczególności w poczekalniach, które Prasad nazywa 'okresami przejściowymi i przestrzeniami pomiędzy'. Przyjazne dzieciom wnętrze również zostało ozdobione pracami plastycznymi znanych artystek. Mieszkańców lasu autorstwa Lucy Casson zainstalowano na wewnętrznych betonowych kolumnach natomiast wróżki Samanthy Bryan znalazły się w okrągłych, przezroczystych kopułach nawiązujących do okien wschodniej elewacji.

Richard Desmond Children's Eye Centre stanowi największy ośrodek badawczy okulistyki pediatrycznej jako połączenie Institute of Ophthalmology i Moorfields Eye Hospital. Został zaprojektowany całkowicie $z$ myślą o dzieciach $i$ ich rodzinach zapewniając im leczenie w najlepszych możliwych okolicznościach. Jak podkreśla prof. Penr T. Khaw 'ten budynek zmienił sposób, w jaki możemy teraz leczyć pacjentów.'

Opracowano na podstawie Children’s Eye Centre, Moorfields Eye Hospital i własnych obserwacji.

\section{WNIOSKI}

Jakość procedur medycznych czy sprzęt używany do badań w krajach rozwiniętych utrzymany jest na podobnym poziomie. To co różni polskie ośrodki okulistyczne od przedstawionych na wybranych przykładach to przede wszystkim komfort pracy personelu i komfort pobytu pacjenta w szpitalu. Spowodowane jest to zbyt małym nakładem finansowym, ponieważ ochrona zdrowia nie jest bezpłatna, a niezwykle kosztowna. Jednym z aspektów, który znacznie utrudnia pracę jest brak odpowiednio dostosowanych pomieszczeń do badan i operacji. Najczęściej publiczne szpitale i przychodnie są osadzone w starych, przedwojennych budynkach gdzie niestety trudno o przekształcenia na większą skalę. W gabinetach występuje często niewystarczająca ilość biurek w stosunku do liczby pracujących lekarzy lub też zbyt mała ilość siedzisk w wąskich poczekalniach gdzie pacjenci i osoby towarzyszące muszą oczekiwać na stojąco, czasem kilka godzin. Trudno jednak oczekiwać rozwiązania problemu funkcjonalności i estetyki pomieszczeń w świetle bardziej pilnych potrzeb jak choćby zwiększenie limitu udzielanych świadczeń czy powszechne braki kadrowe, w wielu grupach personelu medycznego. Warto też zaznaczyć, że zaprezentowane przykłady ośrodków okulistycznych są wzorowe pod wieloma względami a ich powstanie związane było z ogromnym nakładem finansowym oraz zaangażowaniem wielu architektów, konstruktorów oraz innych branżystów i specjalistów. IMO w Barcelonie charakteryzuje się bardzo trafnymi rozwiązaniami pod względem pełnionej funkcji, architektura rozwiązuje kwestie agresywnego światła poprzez odpowiednie zacienianie poszczególnych stref. Dobrym rozwiązaniem w dobie epidemii okazuje się lokowanie ciągów komunikacyjnych między danymi strefami ośrodka na otwartym powietrzu, a gabinety i korytarze we właściwy sposób podzielone odrębnie dla pacjentów i lekarzy. Harkness Eye Institute to dowód na to, że nawet stuletni budynek można przystosować do aktualnych standardów i potrzeb. Children's Eye Centre w Londynie stwarza atmosferę przyjazną dzieciom i pokazuje jak wiele inspiracji można czerpać ze świata medycyny. Zastosowanie przyjaznych pogodnych barw i baśniowych elementów dekoracyjnych stwarza komfortową atmosferę dla młodych pacjentów.

W Polsce jest kilka przykładów częściowo lub całkowicie prywatnych ośrodków wielospecjalistycznych. Nie sposób im jednak konkurować z wyżej wspomnianymi obiektami pod względem architektonicznym, planistycznym, funkcjonalnym oraz estetycznym. Diametralną różnicę generuje choćby dużo większa liczba gabinetów zabiegowych i konsultacyjnych. Opisane wyżej ośrodki powinny służyć jako wzór poprawnych rozwiązań projektowych, ale również organizacji pracy lekarzy i personelu.

\section{BIBLIOGRAPHY}

Children's Eye Centre Hospital, Moorfields Eye Centre. https://www.penoyreprasad.com/project/the-richarddesmond-childrens-eye-centre-moorfields-eye-hospital/?fbclid=IwAR1nZQd7c6_ICq3RL4liJIEGkxf7BIvzD8rBs2cS6 I4IIe54PQXEiH_p-Y. dostep/access 2020-07-10 
Dattner Architects. Harkness Eye Institute. 2017. https://www.world-architects.com/es/dattner-architects-newyork/project/harkness-eyeinstitute?fbclid=IwAR3Ldhhyw9LPiytPjuVEI7kzwYMXNMyGUpi611trenJRQe9OqV fLQ4EYRnA. dostęp/access 2020-06-05

Edward S. Harkness Eye Institute. https://www.columbiaeye.org/about-us/the-harkness-s-eyeinstitute?fbclid=IwAR3Ldhhyw9LPiytPjuVEI7kzwYMXNMyGUpi611trenJRQe9OqVfLQ4EYRnA. dostęp/access 2020-06-05

Harkness Eye Institute. Dattner Architects as Architects. Project 2017. https://archello.com/project/harknesseye-institute-2?fbclid=IwAR3Ldhhyw9LPiytPjuVEI7kzwYMXNMyGUpi611trenJRQe9OqVfLQ4EYRnA. dostęp/access 2020-06-05

IMO Instituto de Microcirugía Ocular Ronda de Dalt http://arcdog.com/portfolio/imo-instituto-de-microcirugiaocular-ronda-dedalt/?fbclid=IwAR3nJBE22EJlh9uKiL1NxKAWE3vF7UZDoGllmqwVvSf5XqRdSgSxrTZrM20. dostęp/access 2020-06-05

IMO Instituto de Microcirugía Ocular, Barcelona. Ocular Microsurgery Institute Barcelona, Spain - design by Josep Llinàs Carmona arch. 15 Nov 2011. https://www.e-architect.co.uk/barcelona/ocular-microsurgeryinstitute?fbclid=IwAR3Ldhhyw9LPiytPjuVEI7kzwYMXNMyGUpi611trenJRQe9OqVfLQ4EYRnA. dostęp/access 2020-02-08

IMO. A benchmark for ocular microsurgery in Barcelona 2013 https://architecturalvisits.com/en/imo-josepIlinas/?fbclid=IwAR3Ldhhyw9LPiytPjuVEI7kzwYMXNMyGUpi611trenJRQe9OqVfLQ4EYRnA. dostęp/access 2020-06-05

Institute of Ocular Microsurgery by Josep Llinás, Barcelona, Spain 1 NOVEMBER 2009. https://www.architectural-review.com/today/institute-of-ocular-microsurgery-by-josep-llinas-barcelonaspain?fbclid=IwAR3Ldhhyw9LPiytPjuVEI7kzwYMXNMyGUpi611trenJRQe9OqVfLQ4EYRnA dostęp/access 2020-02-08

Moorfields Eye Hospital 9 Jan 2019. Moorfields Eye Hospital and UCL Institute of Ophthalmology RIBA Competition 9 Jun 2018. https://www.e-architect.co.uk/london/moorfields-eye-hospital?fbclid=IwAR1 nZQd7c6_ICq3RL4liJIEGkxf7BlvzD8rBs2cS6I4Ile54PQXEiH_p-Y dostep/access 2020-08-10

Moorfields Eye Hospital Children Centre, 2006 with architects Penoyre \& Prasad, London. http://www.yukoshiraishi.com/site/moorfields.html?fbclid=IwAR1nZQd7c6_ICq3RL4liJIEGkxf7BIvzD8rBs2cS6I4Ile54PQXEiH_p-Y dostep/access 2020-10-10

Moorfields Eye Hospital. http://www.publicartonline.org.uk/casestudies/health/moorfields/ima ges.php.html?fbclid=IwAR1-nZQd7c6_ICq3RL4liJIEGkxf7BlvzD8rBs2cS6I4IIe54PQXEiH_p-Y dostep/Access 2020-08-10

Penoyre \& Prasad: www.penoyreprasad.com dostęp / access: 2020-08-10

Richard Desmond Children's Eye Centre https://www.worldarchitecturenews.com/article/1500034/richarddesmond-hildrenseyecentre?fbclid=IwAR1-nZQd7c6_ICq3RL4liJIEGkxf7BlvzD8rBs2cS 6I4lle54PQXEiH_p-Y dostep/access 2020-10-10

\section{O AUTORACH}

Michał Kiszkielis zajmuje się naukowo związkami urbanistyki z ekologią oraz ośrodkami medycznymi, ich funkcjonowaniem i układem architektonicznym. Adriana Kiszkielis jest w trakcie specjalizacji z okulistyki, zawodowo interesuje się neurookulistyką.

\section{ABOUT THE AUTHORS}

Michał Kiszkielis performs research on the links between urban planning combined with ecology and medical facilities, their operation and architectural layout. Adriana Kiszkielis is undergoing ophthalmic specialist training. Her professional interest is neuro-ophthalmology.

Contact | Kontakt: michal.kiszkielis@googlemail.com ; ada.kiszkielis@gmail.com 